\title{
O mundo do mel
}

\author{
Maria Cássia Sobreiro Dias Caldas \\ mcsd.caldas@gmail.com \\ Escola SESI de São João da Boa Vista - São João da Boa Vista - SP - Brasil.
}

\section{Resumo}

Desde o nascimento, diferentes situações colocam as pessoas em contato com as palavras. Elas são ensinadas gradativamente para que possam nomear, reconhecer, dar sentido ao mundo e que tem as necessidades de aprender e desvendar.

Todas as pesquisas desenvolvidas ao longo dos últimos tempos sobre como tornar os alunos leitores competentes têm sido unânimes em afirmar que 0 ato de ler está alicerçado na capacidade humana de compreender e interpretar o mundo.

Os resultados da avaliação externa SARESP de Língua Portuguesa e Redação tem mostrado aos educadores da Escola que deve haver um melhor direcionamento dos trabalhos. Neste sentido, a equipe idealizou um projeto de criação de um livro, "O Mundo do MEL", utilizando a interdisciplinaridade com o componente curricular Arte e os autores serão os alunos.

Os estudantes da Escola participam de Concursos de diversos promotores: As classificações dos estudantes nos concurso são ótimas. 0 projeto vem de encontro a materializar o sucesso dos alunos, que apresenta potencial criativo para desenvolver diferentes habilidades e competências na leitura, escrita e produção de arte, conseqüentemente o sucesso do investimento e a melhoria da aprendizagem.

Para a realização deste empreendimento, o valor solicitado ao edital será de $\mathrm{R} \$ 72.879,07$, destinados à compra de equipamentos, à realização do lançamento do projeto e o lançamento do livro impresso e digital; assim como para despesas correntes de material de consumo, locomoção e serviço terceirizado.

Palavras-chaves: Educação. Interdisciplinaridade. Plano de empreendimento. Leitura. 


\section{Maria Cássia Sobreiro Dias Caldas}

\section{Contexto da escola}

A Escola Escola SESI de São João da Boa Vista foi fundada em 1964 está localizada em São João da Boa Vista, São Paulo, e atende ao ensino fundamental, médio e EJA. A escola tem como missão: Promover a aprendizagem de qualidade e inclusão oferecendo igualdade de condições para acesso e permanência na escolar, e visão: Ser escola de referência formando cidadãos empreendedores com habilidades e competência para atuarem como multiplicadores de conhecimento.

\section{Histórico}

Para atender as exigências do Decreto Federal 50.423 de 08/04/61 que instituiu o salário - educação das indústrias foram criadas as Escolas Primárias SESI.

Em São João da Boa Vista, a pedido da Firma S. A. Moinho Santista Indústrias Gerais foram instaladas em 1.962 o Centro Educacional - SESI - N. 155 no Centro Social São Benedito com 04 classes e o Centro Educacional - SESI - N. ${ }^{\circ} 156$, no prédio do Colégio Comercial "Professor Hugo Sarmento" com 14 classes e em 1.964 a Escolas Reunidas - SESI - N. ${ }^{\circ} 98$ com 02 classes no Bairro Santo Antônio.

Em 1966 as classes foram transferidas para o Centro Educacional - SESI - no. 156. Esta Unidade Escolar foi instalada no Prédio da Prefeitura Municipal "Prefeito Miguel Jorge Nicolau" e está situado à Rua Riachuelo, 444, Bairro Centro, permanecendo até junho de 2011.

Em 25 de julho de 2011 iniciou as atividades da unidade escolar, em prédio próprio à Est. Vicinal João Batista Merlin, 681 - Jd. Itália em S. J. da Boa Vista.

Com a mudança para o prédio próprio a unidade escolar passou a chamar "Escola SESI de São João da Boa Vista" e para os controles internos continuou como Centro Educacional SESI 156.

Atualmente a Escola possui vinte e quatro turmas, sendo:

\begin{tabular}{|c|c|c|c|}
\hline Modalidades & Ano/Série & $\begin{array}{l}N^{\circ} \text {. de } \\
\text { turmas }\end{array}$ & $\begin{array}{l}\text { Total de } \\
\text { Turmas }\end{array}$ \\
\hline \multirow{7}{*}{$\begin{array}{l}\text { Ensino Fundamental de } 9 \text { anos } \\
\text { - Ensino Integral de Tempo } \\
\text { Integral } \\
\text { Fundamental }\end{array}$} & $1^{\circ}$. Ano & 02 & \multirow{6}{*}{12} \\
\hline & $2^{\circ}$. Ano & 02 & \\
\hline & $3^{\circ}$. Ano & 01 & \\
\hline & $4^{\circ}$. Ano & 01 & \\
\hline & $5^{\circ}$. Ano & 02 & \\
\hline & $6^{\circ}$. Ano & 02 & \\
\hline & $7^{\circ}$. Ano & 02 & \\
\hline \multirow{2}{*}{$\begin{array}{c}\text { Ensino Fundamental de } 8 \text { anos } \\
\text { - Tempo Parcial }\end{array}$} & $8^{\circ}$. ano & 02 & \\
\hline & $8^{a}$. Série & 03 & 05 \\
\hline \multirow{3}{*}{ Ensino Médio } & $1^{\circ}$. Ano & 02 & \multirow{3}{*}{05} \\
\hline & $2^{\circ}$. Ano & 02 & \\
\hline & $3^{\circ}$. Ano & 01 & \\
\hline \multirow[t]{2}{*}{ Educação de Jovens e Adultos } & $\begin{array}{l}\text { Ensino } \\
\text { Fundamental }\end{array}$ & 01 & \multirow[t]{2}{*}{02} \\
\hline & Ensino Médio & 01 & \\
\hline \multicolumn{3}{|c|}{ Total de Turmas } & 24 \\
\hline
\end{tabular}


A Escola SESI de São João da Boa Vista, dispõe de dois blocos com dois prédios cada, sendo: salas de aula, sanitário de professor, aluno, alunos com PNE e funcionários - femininos e masculinos, área de circulação - convivência, sala multidisciplinar, sala de Ciência e Tecnologia, sala dos professores, sala de coordenador pedagógico, depósito, copa para funcionários, saguão, laboratório de informática educacional, cozinha e despensa, vestiário de funcionário - feminino e masculino, refeitório, sala de arquivo, secretaria, sala de servidor, sala de administração escolar, sala de atendimento aos pais, almoxarifado, biblioteca escolar, de funcionários.

Existem uma quadra poliesportiva com vestiários feminino e masculino e um playground.

0 material didático construído pela Divisão de Educação do SESI-SP, para ser utilizado pelos estudantes e professores, possibilita o desenvolvimento da competência leitora, por meio do estímulo à pesquisa; a busca de informações na construção e sistematização dos conceitos trabalhados; a interação com textos informativos de diferentes linguagens e 0 aprofundamento de conteúdos. Como a Escola trabalha com 12 turmas de Educação Integral em Tempo Integral do 10 ao 70 ano a equipe escolar possui um momento dentro da formação continuada em serviço, mediada pelos Coordenadores Pedagógicos que planejam e conduzem a Discussão Pedagógica Coletiva na Educação Integral em Tempo Integral.

\section{Perfil dos Alunos e Professores}

A unidade escolar possui 629 alunos matriculados do 10. ano do Ensino Fundamental ao 30. ano do Ensino Médio, dos quais cerca de $43,1 \%$ são beneficiários da indústria, $56,9 \%$ não beneficiários e $52,36 \%$ isentos do pagamento da taxa de escolaridade e mensalidade escolar e 150 alunos da Educação de Jovens e Adultos.

Os alunos são de diferentes níveis socioeconômicos, cultural, crenças, etnias, portanto, heterogênea. Residem em diferentes bairros da cidade, inclusive de cidades visitas.

Existem 10 alunos portadores de necessidades educacionais especiais matriculados nas turmas regulares

Os alunos com deficiência auditiva recebem como complemento para a aprendizagem o Sistema FM e acompanhamento com fonoaudiólogas.

A Equipe docente é formada por vinte e nove professores distribuídos, conforme quadro abaixo: 


\section{Maria Cássia Sobreiro Dias Caldas}

\begin{tabular}{|c|c|}
\hline Modalidades & Quantidade de Professores \\
\hline $\begin{array}{l}\text { Ensino Fund. - Ensino Integral e Tempo } \\
\text { Integral - Do } 1^{\circ} \text {. ao } 5^{\circ} \text {. ano }\end{array}$ & 08 professores \\
\hline 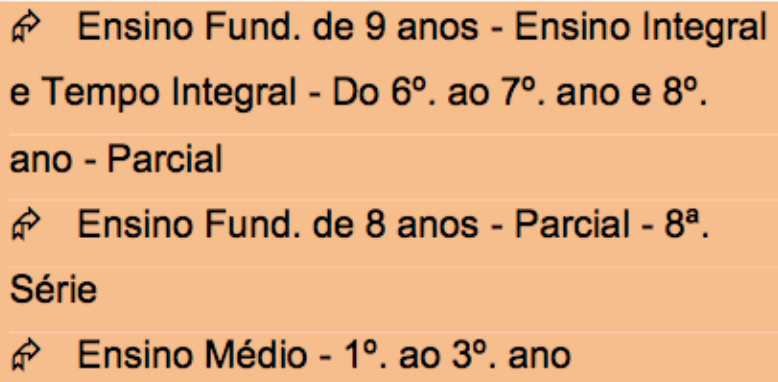 & 19 professores \\
\hline 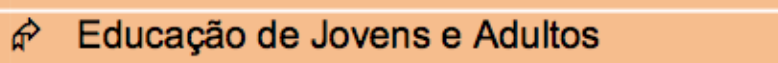 & 02 professores \\
\hline Total & 29 professores \\
\hline
\end{tabular}

Todos os professores possuem formação em nível superior e é comprometida com o trabalho, visando à qualidade da Educação.

A equipe gestora e administrativa mantida pela entidade SESI são compostas por 22 profissionais e 20 profissionais de serviços terceirizados, sendo:

\begin{tabular}{|c|c|c|}
\hline & Cargos & Quantidade de profissionais \\
\hline \multicolumn{3}{|c|}{ Equipe Gestora } \\
\hline$\vec{\omega}$ & Administrador de Unidade Escolar & 01 \\
\hline$\vec{a}$ & Coordenador Pedagógico & 01 \\
\hline \multicolumn{3}{|c|}{ Equipe Administrativa } \\
\hline$\vec{\omega}$ & Professor auxiliar docente & 01 \\
\hline$\vec{a}$ & Analista de Informática Educacional & 01 \\
\hline$\vec{a}$ & Bibliotecária & 01 \\
\hline$\vec{a}$ & Estagiários & 07 \\
\hline$\vec{a}$ & Inspetores de Aluno & 04 \\
\hline$\vec{\omega}$ & Aux. de Serviços Administrativos & 03 \\
\hline$\vec{a}$ & Nutricionista & 01 \\
\hline$\vec{a}$ & Auxiliar de cozinha & 01 \\
\hline$\vec{a}$ & Auxiliar de manutenção & 01 \\
\hline \multicolumn{3}{|c|}{ Equipe terceirizada } \\
\hline$\vec{\omega}$ & Auxiliares de Limpeza & 06 \\
\hline$\vec{\omega}$ & Porteiros & 02 \\
\hline$\vec{a}$ & Jardineiro & 01 \\
\hline$\vec{a}$ & Auxiliar de Manutenção & 01 \\
\hline$\vec{\omega}$ & Vigias & 04 \\
\hline$\vec{\omega}$ & Nutricionista & 01 \\
\hline$\vec{\omega}$ & Auxiliar de cozinha & 06 \\
\hline \multicolumn{2}{|r|}{ Total } & 43 profissionais \\
\hline
\end{tabular}




\section{Características mais marcantes do local onde a escola se insere}

A escola está inserida num bairro a 3,5 km do centro da cidade, seu terreno é margeando por uma rodovia. Possuem três bairros residenciais próximos, um centro de saúde, creche, Instituto Federal e praticamente não existe comércio e sim pastos.

Mesmo distante do centro a unidade escolar atrai muitos alunos por ser bem conceituada na cidade e região, assim como pelo bom trabalho desenvolvido, tendo alcançado as metas do IDEB desde 2005. Há efetiva participação da comunidade local tanto nas atividades propostas, quanto no dia a dia da escola.

\section{Identificação do Problema ou da Oportunidade}

Para tratar da escola, como espaço de leitura e escrita, há a necessidade de se fazer uma inserção na história de cada um.

Desde o nascimento, diferentes situações colocam as pessoas em contato com as palavras. Elas são ensinadas gradativamente para que possam nomear, reconhecer, dar sentido ao mundo e que tem as necessidades de aprender e desvendar.

A leitura e a escrita são atividades dialógicas que ocorrem no meio social através do processo histórico da humanização (FREIRE, 1987). A leitura deve ser a extensão da escola na vida das pessoas para que elas sejam capazes de entender a sociedade em que vivem e transformá-la num mundo melhor e conseqüentemente escrever melhor.

Todas as pesquisas desenvolvidas ao longo dos últimos tempos sobre como tornar os alunos leitores competentes têm sido unânimes em afirmar que 0 ato de ler está alicerçado na capacidade humana de compreender e interpretar o mundo. Precisa-se desenvolver uma prática de leitura prazerosa. Aprende-se a ler lendo e escrevendo. Neste sentido e com a análise dos níveis de proficiência em Língua Portuguesa e Redação nas avaliações externas SARESP (2009 a 2012) da Escola SESI de São João da Boa Vista, conforme quadros e gráficos abaixo:

\begin{tabular}{|l|c|c|c|c|c|c|c|c|}
\hline \multicolumn{7}{|c|}{ Nivel de Proficiência - 5 . Ano } \\
\hline \multirow{2}{*}{ Língua Portuguesa e Redação } \\
\hline
\end{tabular}




\section{Maria Cássia Sobreiro Dias Caldas}

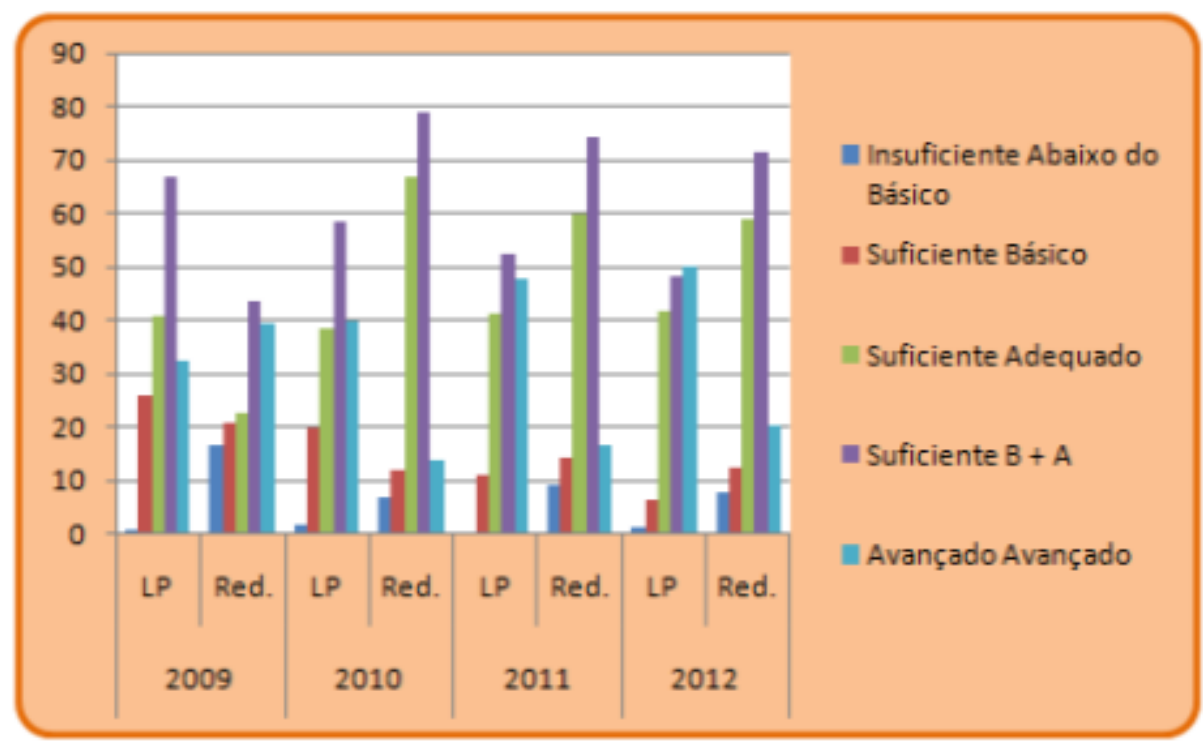

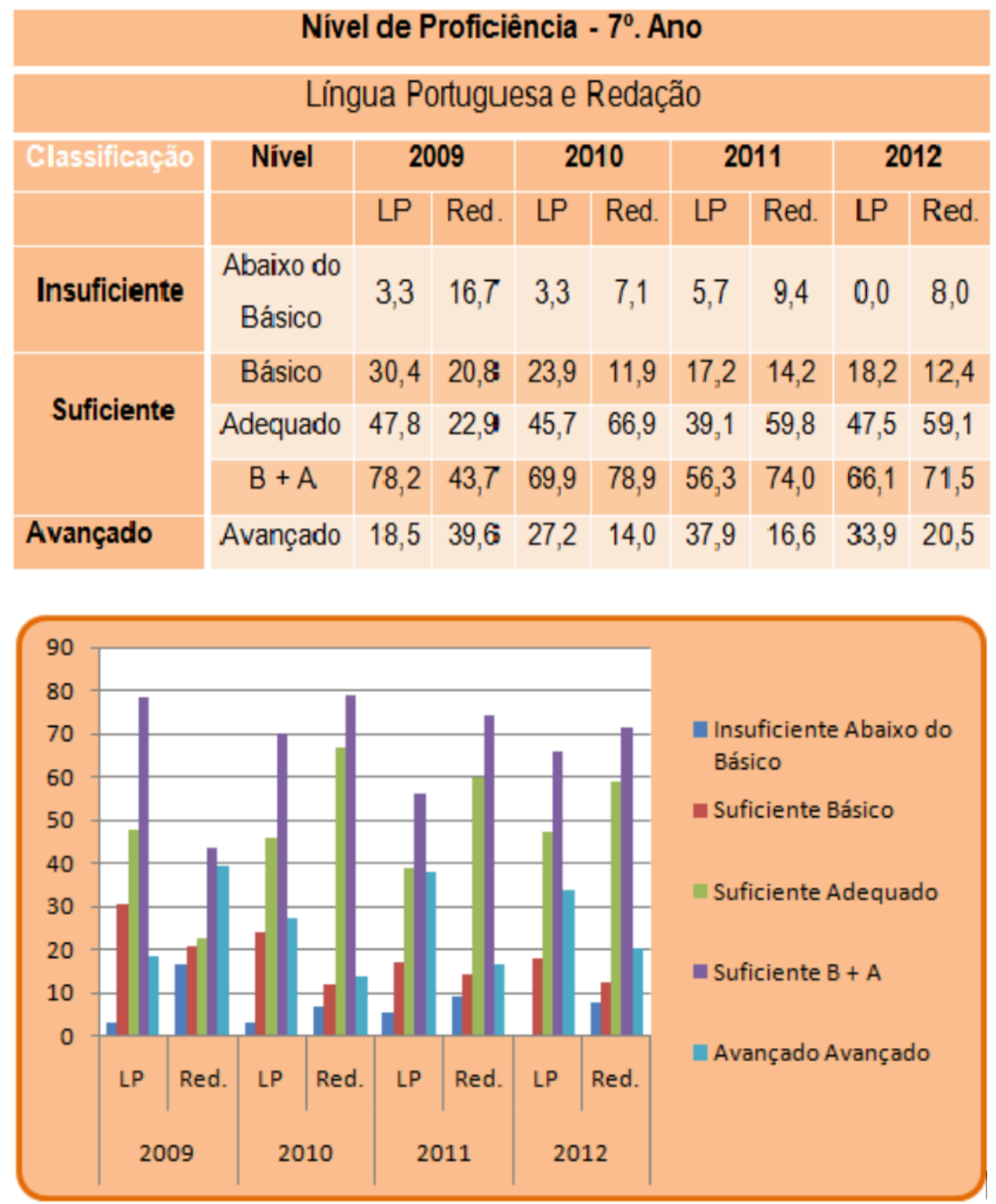




\section{O mundo do mel}

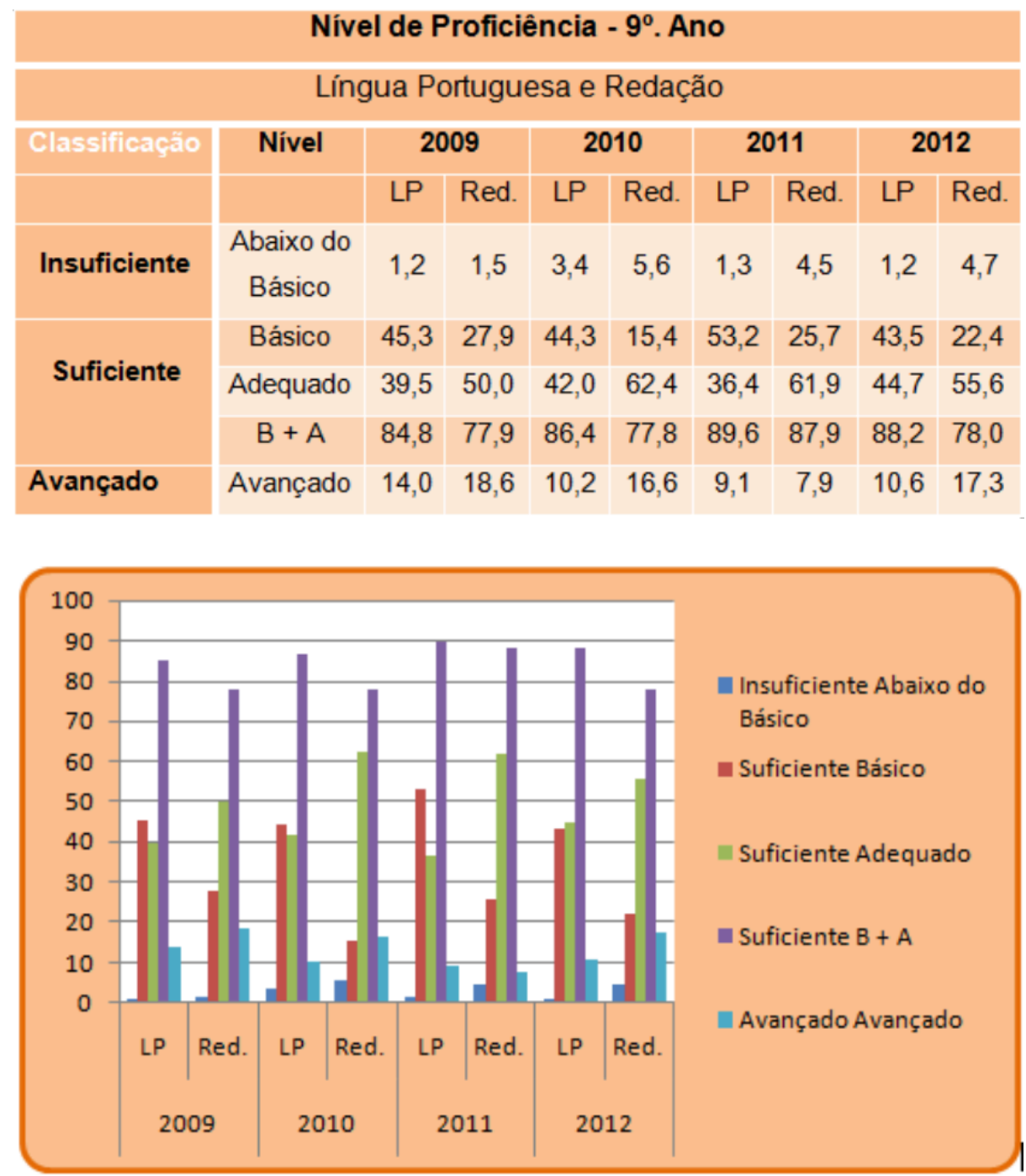

Verifica-se que os resultados do SARESP e das avaliações internas tem mostrado aos educadores da Escola que deve haver um melhor direcionamento dos trabalhos.

Efetuar a previsão de ações que devem ser mantidas ou modificadas, o levantamento do que ainda não foi feito é importante para a melhoria dos resultados.

Objetivando fazer a diferença entre outras escolas avaliadas é necessário elaborar ações mais eficazes, melhorando o trabalho que está sendo desenvolvido, redirecionando a prática pedagógica.

Neste sentido, a equipe, idealizou um projeto de criação de um livro, "O Mundo do MEL"1, utilizando a interdisciplinaridade com o componente curricular Arte e os autores serão os alunos.

Desta maneira o projeto propiciará diferentes formas de ajudar na construção do conhecimento, com leituras e escrita mais participativa, dinâmicas e interessantes de forma mais produtiva.

Este trabalho focado na leitura e escrita estará visando à melhoria da qualidade de ensino em relação à leitura e conseqüentemente na escrita.

Utilizando a ferramenta benchmarking, observamos que algumas escolas da Rede pública e particular, já utilizam projetos de leitura e escrita, com a integração dos diversos componentes curriculares e diversos gêneros literários.

Ensinar a aprender a ler e escrever é tarefa complexa, mas essencial e gratificante se considerar o 
envolvimento de professores e alunos para que ocorra a aquisição da aprendizagem da leitura e da escrita.

\section{Caracterização do serviço}

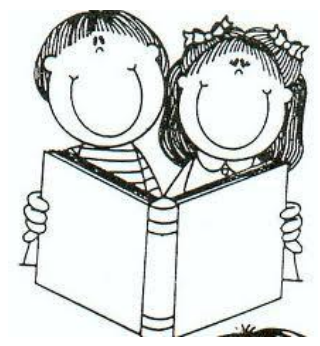

Viajar pela leitura Sem rumo, sem intenção Só para viver a aventura que é ter um livro nas mãos.

(Clarice Pacheco)

\section{Justificativa}

A Escola precisa resgatar a prática da leitura e escrita, especialmente no Ensino Fundamental, com intuito de sanar a dificuldade de aprendizagem. Precisa-se desenvolver uma prática de leitura e escrita prazerosa.

Aprende-se a ler lendo e escrever escrevendo. Por isso este projeto visa a atender essa situação utilizando recursos da leitura e da escrita, incluindo, digitais com meio de estimular 0 aluno e conseqüentemente a melhoria da aprendizagem.

A realização deste projeto na escola apresenta potencial criativo para desenvolver diferentes habilidades e competências dos educandos na leitura, escrita e produção de arte.

O envolvimento dos alunos nas atividades são fatores que apontam para a melhoria do processo educativo, o que dá consistência à execução desse projeto.

\section{Foco do Projeto}

O Projeto de criação e edição de um livro - "O Mundo do MEL - Meu Escrito Literário" atenderá aos alunos da Educação Fundamental do 50., 70. e 9o. ano, envolvendo os componentes curriculares de Língua Portuguesa e Arte.

Com duração de 36 meses, trabalhando no primeiro ano com o 50. ano, no segundo ano com o 70 . ano e no último ano com o 9o.ano.

Ler é considerar aquilo que envolve o mundo do leitor, ou seja, o contexto ligado à experiência de vida de cada ser, para que este possa relacionar seus conceitos prévios com o conteúdo do texto e, dessa forma, construir o sentido.

Ao considerar como leitura suas experiências e vivências, a leitura se tornará uma prática muito mais ampla e viva, na qual o pulsar das informações baterá no mesmo ritmo das emoções em forma de escrita.

Este projeto tem como objetivo uma aprendizagem abrangente, real, aplicada na vida do aluno, na forma de ler e escrever. Queremos que haja satisfação durante a vivência e criação do livro. 


\section{0 mundo do mel}

Esquema representativo das principais etapas do projeto

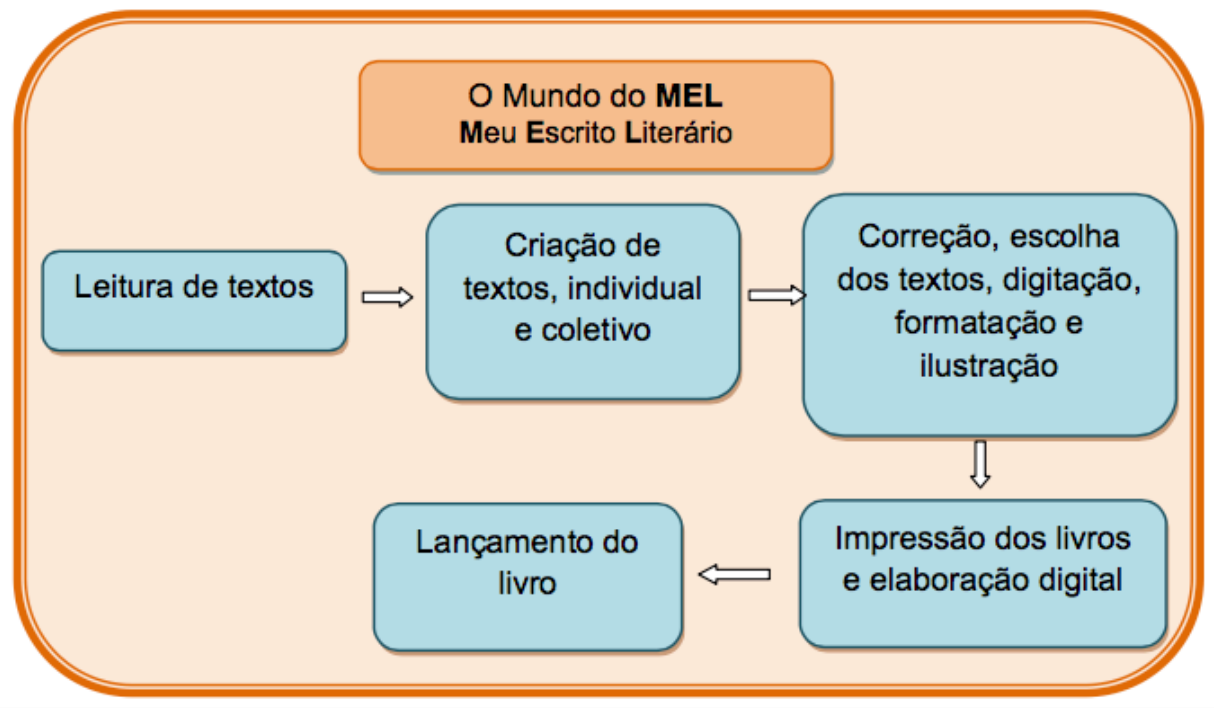

\section{Etapas do projeto}

\begin{tabular}{|c|c|}
\hline Etapa & Descrição \\
\hline 1 & $\begin{array}{l}\text { Elaboração do projeto. } \\
\text { Reunião com os professores de Língua Portuguesa e Arte para } \\
\text { definições do projeto. }\end{array}$ \\
\hline 2 & $\begin{array}{l}\text { Apresentação do projeto a equipe escolar } \\
\text { Reunião com a equipe escolar e fazer parcerias (analista de } \\
\text { informática educacional, bibliotecária e demais professores). }\end{array}$ \\
\hline 3 & $\begin{array}{l}\text { Lançamento do projeto } \\
\& \text { Divulgação do projeto aos alunos e pais. }\end{array}$ \\
\hline 4 & $\begin{array}{l}\text { Retomar conhecimentos } \\
\text { Reorientação dos professores de Língua Portuguesa sobre os } \\
\text { diversos gêneros literários. } \\
\text { Orientação do professor Orientação de Estudo sobre as partes de } \\
\text { um livro e pela professora de Arte sobre modalidades de desenho } \\
\text { e pintura para as ilustrações do livro e capa. }\end{array}$ \\
\hline 5 & $\begin{array}{l}\text { Desenvolver a leitura prazerosa } \\
\text { Desenvolvimento de leituras de diversos gêneros literários, com } \\
\text { orientação dos professores de Língua Portuguesa, Orientação de } \\
\text { estudo e bibliotecária. }\end{array}$ \\
\hline 6 & $\begin{array}{l}\text { Conhecer a Academia São-joanense de Letras e contatar alguns } \\
\text { escritores da cidade } \\
\text { Excursão à Academia Sãojoanense de Letras para palestra e } \\
\text { plenária com alguns escritores. }\end{array}$ \\
\hline 7 & $\begin{array}{l}\text { Desenvolver a escrita em diversos gêneros } \\
\text { Criação de textos pelos alunos, individual e em conjunto. Os } \\
\text { alunos escolheram os gêneros e os temas. }\end{array}$ \\
\hline
\end{tabular}




\begin{tabular}{c|l}
\hline 8 & $\begin{array}{l}\text { Orientar os alunos referentes aos acertos e erros } \\
\text { Correção dos textos pelos professores de Língua Portuguesa e de } \\
\text { Orientação de Estudo, escolha dos textos para a edição do livro e } \\
\text { criação do título. }\end{array}$ \\
\hline 9 & $\begin{array}{l}\text { Conhecer os diversos tipos de livros - impresso e digital } \\
\text { Pesquisa no laboratório de informática com orientação da analista } \\
\text { de informática. }\end{array}$ \\
\hline 10 & $\begin{array}{l}\text { Editar e elaborar o livro impresso e digital } \\
\text { Digitação, formatação, impressão dos textos e elaboração digital. }\end{array}$ \\
\hline 12 & $\begin{array}{l}\text { Orientar os alunos referentes às ilustrações dos textos e criar a capa } \\
\text { Desenvolvimento das ilustrações através de desenhos e pinturas. } \\
\text { Publicar o livro } \\
\text { \& Impressão do livro na gráfica }\end{array}$ \\
\hline 13 & $\begin{array}{l}\text { Lançar o livro } \\
\text { Realização de noite de autógrafos com presente da comunidade } \\
\text { escolar. }\end{array}$ \\
\hline
\end{tabular}

\section{Exemplos de Projetos Similares}

$\mathrm{Na}$ Escola Estadual Engenheiro Caldas2 o projeto "Leitura e criação de histórias em quadrinhos", e na Escola Classe 18 de Taguatinga3 com o Projeto de Quadrinhos na Escola são exemplos de sucesso.

0 envolvimento dos alunos nas atividades são fatores que apontam para a melhoria do processo educativo, o que dá consistência à execução do mesmo. Os resultados obtidos:

- Disposição, motivação e entusiasmo pelas atividades realizadas.

- Despertou nos alunos o interesse pela leitura e escrita.

- Amadurecimento da linguagem oral e escrita e disposição para a busca de novos conhecimentos.

- Aumento da compreensão e interpretação da leitura, apresentando melhores resultados no processo de ensino-aprendizagem escolar.

Os resultados demonstram o grande envolvimento da equipe docente e alunos que fazem o projeto acontecer.

\section{Continuidade/evolução do Projeto}

Os estudantes da Escola participam de Concursos de diversos promotores: Concurso Literário de Poesia e Prosa Internacional e Concurso de Redação na Escola da Academia de Letras de São João da Boa Vista, Concurso de Redação da Prefeitura Municipal de São João da Boa Vista - Dia das Mães e Pais, Concurso Cartas dos Correios. A oitava série participa do concurso EPTV - Redação.

As classificações dos estudantes nas participações nos concurso são ótimas. 0 projeto vem de encontro a materializar o sucesso dos alunos.

A intenção é continuar apoiando os mesmos nas participações e nas edições futuras de livro impresso e digital, consolidando o projeto e tornando um processo constante na unidade escolar. 


\section{O mundo do mel}

\section{Estratégia de implementação}

\section{Análise SWOT}

Forças

- A Equipe gestora e docentes empenhados em desenvolver um ensino de qualidade e de novas oportunidades de aprendizagem.

- Alunos interessados nas atividades diversificadas desenvolvidas para a melhoria da aprendizagem.

- Apoio da comunidade escolar, principalmente dos pais dos alunos.

Fraquezas

- Insegurança e resistência de alguns professores, quanto ao desenvolvimento de novas oportunidades de aprendizagem.

\section{Oportunidades}

- Participação dos alunos em diversos concursos desenvolvidos na cidade.

- O conceito da unidade escola na cidade e região.

- Apoio da Academia Sãojoanense de Letras e o Jornal "Edição Extra" às iniciativas da escola.

\section{Ameaças}

- Alteração dos diretores e dirigentes e não garantir a continuidade do projeto.

- Falta de recursos para a continuação do projeto em anos futuros.

Objetivos, Metas e Estratégias

\begin{tabular}{|c|c|c|}
\hline Objetivos & Metas & Estratégias \\
\hline $\begin{array}{c}\text { Melhoria das } \\
\text { aprendizagens } \\
\text { abrangente, real, } \\
\text { aplicada na vida } \\
\text { do aluno, por } \\
\text { meio do } \\
\text { desenvolvimento } \\
\text { da competência } \\
\text { da leitura e da } \\
\text { escrita. }\end{array}$ & $\begin{array}{l}\text { Editar } 80 \% \text { dos textos } \\
\text { produzidos pelos } \\
\text { alunos, em livro } \\
\text { impresso e digital. } \\
\text { (36 meses). }\end{array}$ & $\begin{array}{l}\text { Realização de reuniões } \\
\text { Lançamento do projeto à } \\
\text { comunidade escolar } \\
\text { Desenvolvimento de leituras de } \\
\text { diversos gêneros literários. } \\
\text { Excursão à Academia } \\
\text { Sãojoanense de Letras } \\
\text { Criação de textos individuais e } \\
\text { coletivos. } \\
\text { Correção escolher os textos } \\
\text { para a edição do livro e criação } \\
\text { do título. } \\
\text { Pesquisa sobre os diversos } \\
\text { tipos de livros - impresso e } \\
\text { digital } \\
\text { Digitação, formatação dos } \\
\text { textos e ilustrações. } \\
\text { Elaboração do livro digital. } \\
\text { Impressão do livro na gráfica. } \\
\text { Imealização de noite de } \\
\text { autógrafos com presente da } \\
\text { comunidade escolar }\end{array}$ \\
\hline
\end{tabular}


Maria Cássia Sobreiro Dias Caldas

\begin{tabular}{|c|c|c|}
\hline $\begin{array}{c}\text { Evoluir os } \\
\text { indices das } \\
\text { avaliações } \\
\text { externas e } \\
\text { internas, } \\
\text { SARESP em } \\
\text { Língua } \\
\text { Portuguesa e } \\
\text { Redação }\end{array}$ & $\begin{array}{l}\text { Aumentar o interesse } \\
\text { dos alunos para a } \\
\text { aprendizagem, leitura } \\
\text { e escrita, elevando o } \\
\text { desempenho escolar } \\
\text { em } 20 \% \text { por ano. } \\
\text { (a cada } 12 \text { meses) }\end{array}$ & $\begin{array}{l}\text { Conscientização do corpo } \\
\text { docente para aplicação de } \\
\text { atividades diversificadas } \\
\text { estimulando a criatividade do } \\
\text { aluno e desenvolvendo o gosto } \\
\text { pela leitura e escrita }\end{array}$ \\
\hline
\end{tabular}

Plano de ação (5W2H)

\begin{tabular}{|c|c|c|c|c|c|}
\hline 0 que? & Onde? & Quando? & Por quê? & Quem? & Como? \\
\hline $\begin{array}{l}\text { Realizar } \\
\text { reunião }\end{array}$ & $\begin{array}{l}\text { Sala } \\
\text { Multidisciplinar }\end{array}$ & Janeiro & $\begin{array}{l}\text { Para definições } \\
\text { do projeto e } \\
\text { fazer parcerias }\end{array}$ & $\begin{array}{l}\text { Adm. } \\
\text { Escolar } \\
\text { Coord. } \\
\text { Pedagógico } \\
\text { Equipe } \\
\text { docente } \\
\text { Analista de } \\
\text { informática } \\
\text { Bibliotecária }\end{array}$ & $\begin{array}{l}\text { Identificação } \\
\text { dos itens a } \\
\text { serem } \\
\text { trabalhados, } \\
\text { sugestões e } \\
\text { parcerias }\end{array}$ \\
\hline $\begin{array}{l}\text { Divulgar o } \\
\text { projeto }\end{array}$ & $\begin{array}{l}\text { Área de } \\
\text { convivência }\end{array}$ & Fevereiro & $\begin{array}{l}\text { Para comunicar } \\
\text { os alunos e pais }\end{array}$ & $\begin{array}{l}\text { Equipe } \\
\text { escolar } \\
\text { alunos } \\
\text { Pais }\end{array}$ & $\begin{array}{l}\text { Apresentação } \\
\text { de slides das } \\
\text { etapas do } \\
\text { projeto e } \\
\text { gráficos dos } \\
\text { resultados do } \\
\text { SARESP, } \\
\text { Banner, folder e } \\
\text { artigo em } \\
\text { jornais }\end{array}$ \\
\hline $\begin{array}{l}\text { Realizar } \\
\text { leitura } \\
\text { prazerosa }\end{array}$ & $\begin{array}{l}\text { Biblioteca e } \\
\text { Ambientes } \\
\text { diversos }\end{array}$ & Março & $\begin{array}{l}\text { Para } \\
\text { Desenvolvimento } \\
\text { de leituras de } \\
\text { diversos gêneros }\end{array}$ & Alunos & $\begin{array}{l}\text { Orientação dos } \\
\text { profos. de L. } \\
\text { Portuguesa, O. } \\
\text { de Estudo } \\
\text { Bibliotecária }\end{array}$ \\
\hline $\begin{array}{l}\text { Realizar } \\
\text { excursão }\end{array}$ & $\begin{array}{l}\text { Academia } \\
\text { Sãojoanense } \\
\text { de Letras }\end{array}$ & Abril & $\begin{array}{l}\text { Para conhecer, } \\
\text { ter contato com } \\
\text { alguns escritores } \\
\text { e palestra }\end{array}$ & $\begin{array}{l}\text { Professores } \\
\text { Alunos }\end{array}$ & $\begin{array}{l}\text { Conhecimento e } \\
\text { discussão. }\end{array}$ \\
\hline $\begin{array}{l}\text { Produzir } \\
\text { textos }\end{array}$ & $\begin{array}{l}\text { Sala de aula } \\
\text { Biblioteca } \\
\text { Em casa }\end{array}$ & Junho & $\begin{array}{l}\text { Para } \\
\text { desenvolvimento } \\
\text { da escrita em } \\
\text { diversos gêneros } \\
\text { com } \\
\text { textos individuais } \\
\text { e coletivos }\end{array}$ & Alunos & $\begin{array}{l}\text { Escolha do } \\
\text { tema e gênero }\end{array}$ \\
\hline $\begin{array}{l}\text { Corrigir, } \\
\text { escolher os } \\
\text { textos para } \\
\text { a edição do } \\
\text { livro e } \\
\text { criação do } \\
\text { título. }\end{array}$ & $\begin{array}{l}\text { Sala de aula } \\
\text { Biblioteca }\end{array}$ & Agosto & $\begin{array}{l}\text { Para orientar os } \\
\text { alunos } \\
\text { referentes aos } \\
\text { acertos e erros e } \\
\text { escola dos } \\
\text { títulos }\end{array}$ & $\begin{array}{l}\text { Profos. de } \\
\text { Língua } \\
\text { Portuguesa }\end{array}$ & $\begin{array}{l}\text { Analise os } \\
\text { textos e } \\
\text { orientando os } \\
\text { alunos }\end{array}$ \\
\hline
\end{tabular}




\section{O mundo do mel}

\begin{tabular}{l|l|l|l|l|l}
$\begin{array}{l}\text { Orientar e } \\
\text { criar as } \\
\text { ilustrações } \\
\text { dos textos } \\
\text { e capa }\end{array}$ & Sala de Aula & Novembro & $\begin{array}{l}\text { Para ilustrar os } \\
\text { textos e criar a } \\
\text { capa }\end{array}$ & $\begin{array}{l}\text { Alunos e } \\
\text { profä. de } \\
\text { Arte }\end{array}$ & $\begin{array}{l}\text { Através de } \\
\text { desenhos e } \\
\text { pintura }\end{array}$ \\
\hline $\begin{array}{l}\text { Publicar o } \\
\text { livro }\end{array}$ & Gráfica & Dezembro & $\begin{array}{l}\text { Para finalizar o } \\
\text { projeto }\end{array}$ & Gráfica & Impressão \\
\hline $\begin{array}{l}\text { Lançar o } \\
\text { livro }\end{array}$ & $\begin{array}{l}\text { Área de } \\
\text { Convivência }\end{array}$ & Dezembro & $\begin{array}{l}\text { Para lançar o } \\
\text { livro e finalizar o } \\
\text { projeto }\end{array}$ & $\begin{array}{l}\text { Equipe } \\
\text { Gestora } \\
\text { Corpo } \\
\text { docente e } \\
\text { discente } \\
\text { Pais }\end{array}$ & $\begin{array}{l}\text { Realizando uma } \\
\text { noite de } \\
\text { autógrafos e } \\
\text { coquetel. }\end{array}$ \\
\hline $\begin{array}{l}\text { Evoluir os } \\
\text { indices }\end{array}$ & $\begin{array}{l}\text { Avaliações } \\
\text { externas e } \\
\text { internas, } \\
\text { SARESP em } \\
\text { Língua } \\
\text { Portuguesa e } \\
\text { Redação. }\end{array}$ & Novembro & $\begin{array}{l}\text { Para aumentar o } \\
\text { interesse dos } \\
\text { alunos para a } \\
\text { aprendizagem, } \\
\text { leitura e escrita, } \\
\text { elevando o } \\
\text { desempenho } \\
\text { escolar em 20\% } \\
\text { por ano. }\end{array}$ & $\begin{array}{l}\text { Equipe } \\
\text { Docente } \\
\text { Alunos }\end{array}$ & $\begin{array}{l}\text { Conscientização } \\
\text { do corpo } \\
\text { docente para } \\
\text { aplicação de } \\
\text { atividades } \\
\text { diversificadas } \\
\text { estimulando a } \\
\text { criatividade do } \\
\text { aluno e } \\
\text { desenvolvendo } \\
\text { o gosto pela } \\
\text { leitura e escrita. }\end{array}$ \\
\hline
\end{tabular}

Os custos serão apresentados nas planilhas financeiras

\section{Indicadores para Acompanhamento}

Todo plano de ação deve ser monitorado. Para este monitoramento são utilizados os indicadores que permitem comprovar a progressão de um projeto.

O acompanhamento acontecerá de forma contínua e paralela e em todos os momentos em que os alunos estiverem participando das atividades, das

discussões propostas, demonstrando interesse em desenvolver tais atividades.

Indicadores:

- Participação dos alunos no projeto - Disposição, motivação e. entusiasmo pelas atividades realizadas;

- Aprendizagem - Amadurecimento da linguagem oral e escrita e disposição para a busca de novos conhecimentos e criação de textos com coerência e coesão, com correta utilizando diferentes gêneros textuais.

- Utilização da verba destinada ao desenvolvimento do projeto

Para o monitoramento será utilizado o relatório de acompanhamento dos indicadores. 


\section{Maria Cássia Sobreiro Dias Caldas}

\section{Recursos Necessários}

\begin{tabular}{|c|c|c|}
\hline $\begin{array}{l}\text { O que vou } \\
\text { precisar }\end{array}$ & Descrição & Como obter \\
\hline $\begin{array}{l}\text { Diagramação e } \\
\text { impressão dos } \\
\text { livros }\end{array}$ & $\begin{array}{l}\text { O livro é o produto final do } \\
\text { projeto }\end{array}$ & Recursos obtidos do Edital \\
\hline $\begin{array}{l}\text { Verba para } \\
\text { excursão }\end{array}$ & $\begin{array}{l}\text { Necessário para realizar uma } \\
\text { etapa do projeto }\end{array}$ & Recursos obtidos do Edital \\
\hline $\begin{array}{l}\text { Verba para coffe } \\
\text { break e coquetel }\end{array}$ & $\begin{array}{l}\text { Para realizar a apresentação } \\
\text { aos pais e lançamento do livro }\end{array}$ & Recursos obtidos do Edital \\
\hline $\begin{array}{c}\text { Compra de } \\
\text { notebook, } \\
\text { impressora, } \\
\text { projetor de } \\
\text { multimídia com } \\
\text { tela de projeção, } \\
\text { caixa amplificada e } \\
\text { microfone sem fio }\end{array}$ & $\begin{array}{l}\text { Para uso dos alunos, } \\
\text { apresentação e lançamento do } \\
\text { projeto }\end{array}$ & Recursos obtidos do Edital \\
\hline $\begin{array}{l}\text { Verba para o } \\
\text { marketing }\end{array}$ & $\begin{array}{l}\text { Para realizar o marketing e } \\
\text { comunicação do projeto }\end{array}$ & Recursos obtidos do Edital \\
\hline $\begin{array}{l}\text { Profissionais para } \\
\text { atual no projeto }\end{array}$ & $\begin{array}{c}\text { Administrador de U. Escolar, } \\
\text { Coordenador Pedagógico, } \\
\text { Professor de Língua } \\
\text { Portuguesa, Professor de Arte, } \\
\text { Professor Orientador de } \\
\text { Estudo, Analista de Informática } \\
\text { e Bibliotecária. } \\
\text { Para acompanhamento e } \\
\text { orientação }\end{array}$ & $\begin{array}{c}\text { Recursos obtidos da } \\
\text { contrapartida da instituição }\end{array}$ \\
\hline
\end{tabular}

\section{Marketing e Comunicação}

Philip Kotler define o composto de Marketing como "o conjunto de ferramentas que a empresa usa para atingir seus objetivos de marketing no mercado alvo".

O Mix de Marketing é formado por produto, preço, praça e promoção, e é a combinação de ferramentas estratégicas usadas para criar valor para os clientes.

Utilizando do composto de marketing as ferramentas visam atingir o objetivo de divulgação do projeto "O Mundo do Mel". 


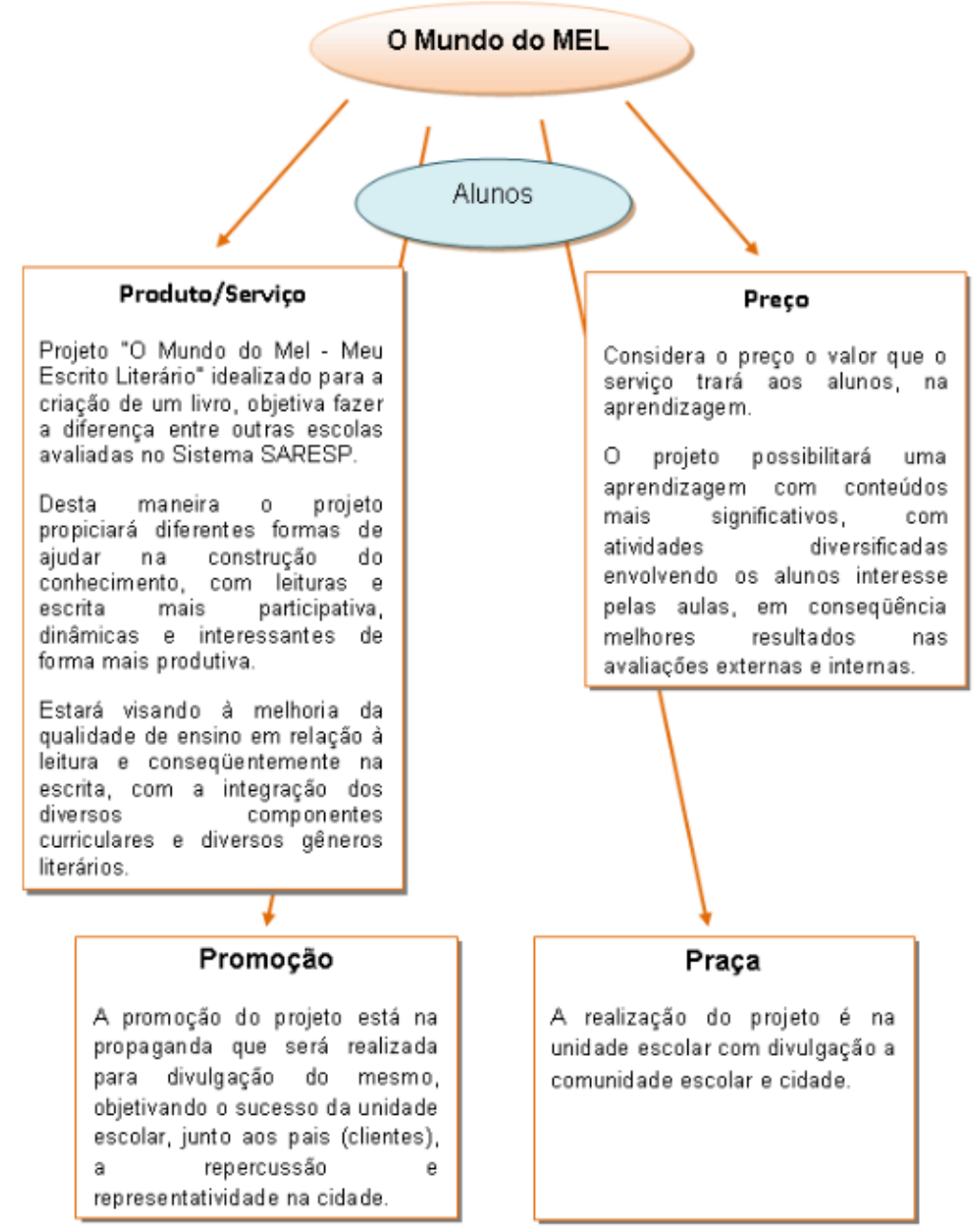

A comunicação da implantação em 2014 iniciará com o marketing integrado, onde o Administrador Escolar fará a divulgação do projeto à equipe escolar em reunião, com objetivo que toda unidade escolar se volte para o sucesso do projeto com empenho, comprometimento de todos e a perfeita comunicação a comunidade escolar.

Posteriormente será realizado o lançamento do projeto junto aos demais funcionários da unidade escolar, alunos e pais. A apresentação será através de reunião com apresentação em slides das etapas do projeto e gráficos sobre os resultados do SARESP, entrega de Folder. Será oferecido um coffe break aos presentes no lançamento do projeto.

A unidade escolar se mobilizará para o sucesso do evento com colocação de Banners em diversos pontos e artigo sobre o lançamento do projeto nos jornais da cidade.

A comunicação do lançamento do livro impresso e digital, em noite de autógrafos com coquetel, será realizada através de convite a comunidade escolar e matéria nos jornais da cidade.

O projeto "Meu Mundo do MEL" foi elaborado visando à melhoria da aprendizagem dos alunos e tudo indica que será bem aceito pela comunidade escolar. A diversificação das atividades atende às necessidades da melhoria da qualidade de ensino e vem beneficiar a unidade escolar em sua classificação no SARESP e conseqüentemente no IDEB. 


\section{Maria Cássia Sobreiro Dias Caldas}

\section{Organização e gerência do empreendimento Organograma e Funções}

A organização e gerência do empreendimento serão feitas pela equipe gestora da unidade escolar, coordenador pedagógico, corpo docente e demais analista.

Para melhor visualização segue abaixo o organograma representativo da estrutura do projeto "O Mundo do Mel".

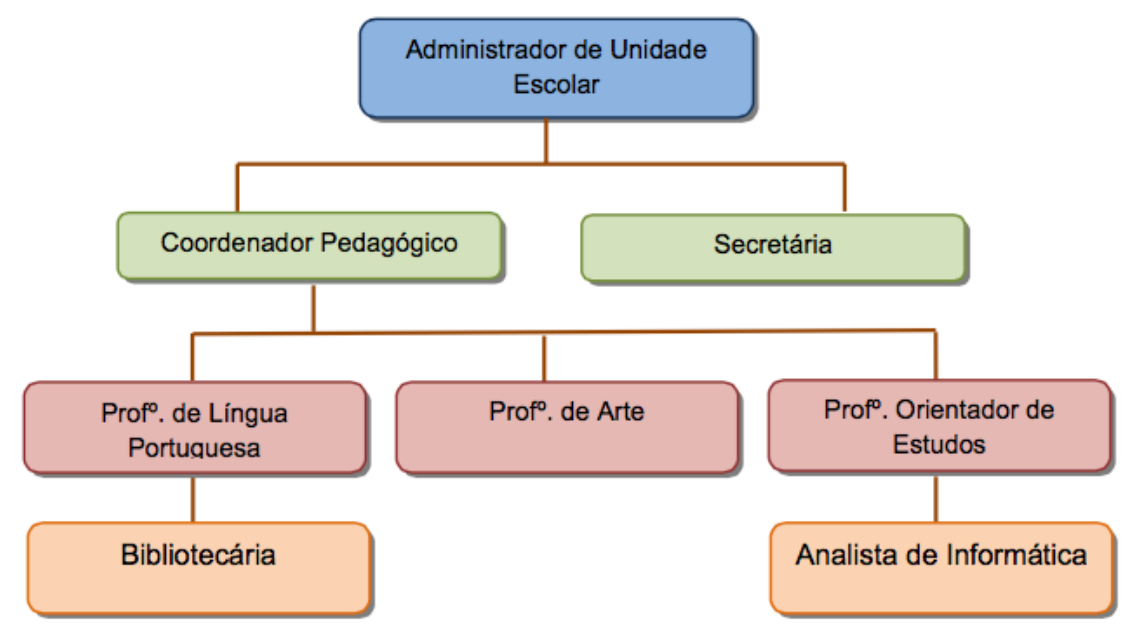

\begin{tabular}{|c|c|}
\hline Função & Formação/Experiência \\
\hline $\begin{array}{l}\text { Administrador } \\
\text { de Unidade } \\
\text { Escolar }\end{array}$ & $\begin{array}{l}\text { Cursa MBA Gestão Empreendedora em Educação. } \\
\text { Desempenha a função há } 22 \text { anos na Rede SESI. } \\
\text { Professora por } 15 \text { anos de Arte e Administrador de Unidade } \\
\text { Escolar há } 7 \text { anos. }\end{array}$ \\
\hline $\begin{array}{l}\text { Coordenador } \\
\text { Pedagógico }\end{array}$ & $\begin{array}{l}\text { Formação em Pedagogia. } \\
\text { Desempenha funções na Rede SESI há } 22 \text { anos. } \\
\text { Professora de } 1^{\circ} \text { ao } 5^{\circ} \text {. ano por } 19 \text { anos e atualmente } \\
\text { coordenadora pedagógica há } 3 \text { anos }\end{array}$ \\
\hline Secretária & $\begin{array}{l}\text { Formação em Administração de empresas e Letras } \\
\text { Executa suas funções de secretária na unidade escolar há } \\
38 \text { anos. }\end{array}$ \\
\hline $\begin{array}{l}\text { Professor de } \\
\text { Língua } \\
\text { Portuguesa }\end{array}$ & $\begin{array}{l}\text { Formação em Letras - Português/lnglês. } \\
\text { Ministra aula há } 38 \text { anos, atualmente nos } 5^{\circ} \text { e } 7^{\circ} \text { ano do } \\
\text { Ensino Fundamental. }\end{array}$ \\
\hline
\end{tabular}




\begin{tabular}{l|l}
\hline $\begin{array}{l}\text { Professor de } \\
\text { Arte }\end{array}$ & $\begin{array}{l}\text { Formação em Arte - Desenho. } \\
\text { Ministra aula há 10 anos, na unidade escolar, atualmente de } \\
5^{\circ} \text { ao } 9^{\circ} \text { ano do Ensino Fundamental e } 1^{\circ} \text {. ao } 3^{\circ} \text { ano do } \\
\text { Ensino Médio. } \\
\text { Pintora renomada na região e excelente retratista. }\end{array}$ \\
\hline $\begin{array}{l}\text { Professor } \\
\text { Estudador de }\end{array}$ & $\begin{array}{l}\text { Formação em Pedagogia. } \\
\text { Ministra aula do } 6^{\circ} \text { ao } 7^{\circ} \text {. ano de orientação de estudos. } \\
\text { Executa suas funções de professor há } 20 \text { anos. } \\
\text { Anteriormente exerceu a função de coordenação na própria } \\
\text { unidade escolar. }\end{array}$ \\
\hline Bibliotecária & $\begin{array}{l}\text { Formação em Biblioteconomia. } \\
\text { Executa suas funções há 4 anos nesta unidade escolar. } \\
\text { Formada em contadora de estórias e técnicas de origami. }\end{array}$ \\
\hline $\begin{array}{l}\text { Analista de } \\
\text { Informática }\end{array}$ & $\begin{array}{l}\text { Cursa mestrado sobre informática na educação. } \\
\text { Executa suas funções na unidade escolar há } 4 \text { anos, no } \\
\text { laboratório da informática educacional e participa do Projeto } \\
\text { de Robótica/Lego. }\end{array}$
\end{tabular}

\section{Principais Processos}

Os principais processos do projeto "O Mundo do Mel" estão relacionados na tabela abaixo:

\begin{tabular}{|c|c|c|}
\hline $\begin{array}{l}\text { Processos do seu } \\
\text { empreendimento }\end{array}$ & Colaborador & Perfil necessário \\
\hline $\begin{array}{c}\text { Prestar contas das } \\
\text { verbas destinadas ao } \\
\text { projeto }\end{array}$ & $\begin{array}{c}\text { Maria Cássia } \\
\text { Administrador de } \\
\text { Unidade Escolar }\end{array}$ & $\begin{array}{l}\text { Conhecimento: Gestão Escolar e } \\
\text { Financeira. } \\
\text { Habilidade: Mobiliar recursos para a } \\
\text { unidade escolar. } \\
\text { Atitude: Responsabilidade e } \\
\text { comprometimento. }\end{array}$ \\
\hline $\begin{array}{c}\text { Realizar reuniões } \\
\text { para apresentação do } \\
\text { projeto e organizar o } \\
\text { evento de } \\
\text { lançamento do } \\
\text { projeto e do livro }\end{array}$ & $\begin{array}{l}\text { Administrador de } \\
\text { Unidade Escolar }\end{array}$ & $\begin{array}{l}\text { Conhecimento: Gestão Escolar e o } \\
\text { projeto "O Mundo do Mel". } \\
\text { Habilidade: Planejar e organizar } \\
\text { reuniões, comunicação. } \\
\text { Atitude: Responsabilidade, } \\
\text { comprometimento e ética. }\end{array}$ \\
\hline
\end{tabular}


Maria Cássia Sobreiro Dias Caldas

\begin{tabular}{|c|c|c|}
\hline $\begin{array}{l}\text { Acompanhar a parte } \\
\text { pedagógica do } \\
\text { projeto junto aos } \\
\text { professores e } \\
\text { assessorar a } \\
\text { organização dos } \\
\text { eventos de } \\
\text { lançamento do } \\
\text { projeto e do livro e } \\
\text { excursão. }\end{array}$ & $\begin{array}{l}\text { Coordenador } \\
\text { Pedagógico }\end{array}$ & $\begin{array}{l}\text { Conhecimento: O projeto "O Mundo do } \\
\text { Mel". } \\
\text { Habilidade: Dominar os processos } \\
\text { pedagógicos, trabalhar em equipe, boa } \\
\text { comunicação e participar da gestão do } \\
\text { projeto. } \\
\text { Atitude: Responsabilidade, } \\
\text { comprometimento e ética. }\end{array}$ \\
\hline $\begin{array}{l}\text { Executar os } \\
\text { orçamentos, compras } \\
\text { e atividades de apoio } \\
\text { aos gestores. }\end{array}$ & Secretária & $\begin{array}{l}\text { Conhecimento: Processos } \\
\text { administrativos: orçamentos e demais } \\
\text { atividades de apoio ao projeto "O } \\
\text { Mundo do Mel". } \\
\text { Habilidade: Dominar os processos } \\
\text { administrativos necessários para apoio } \\
\text { aos gestores do projeto, trabalhar em } \\
\text { equipe, boa comunicação e participar } \\
\text { da gestão do projeto. } \\
\text { Atitude: Responsabilidade, } \\
\text { comprometimento, agilidade, autonomia } \\
\text { e organização. }\end{array}$ \\
\hline $\begin{array}{c}\text { Orientar as } \\
\text { ilustrações dos textos } \\
\text { e criação da capa. } \\
\text { Acompanhar o } \\
\text { processo de criação } \\
\text { do livro - ilustração } \\
\text { dos textos e criação } \\
\text { da capa. }\end{array}$ & Professora de Arte & $\begin{array}{l}\text { Conhecimento: Professora experiente } \\
\text { de Arte. Excelente pintora, dedicada a } \\
\text { aos projetos da escola. } \\
\text { Habilidade: Organizar e estimular } \\
\text { situações de aprendizagem, incentivar } \\
\text { e envolver os alunos em suas } \\
\text { aprendizagens, trabalhar em equipe. } \\
\text { Atitude: Respeitar e valorizar o ser } \\
\text { humano em suas potencialidades, } \\
\text { criatividade, flexibilidade, autonomia, } \\
\text { trabalhar em parceria com outros } \\
\text { profissionais. }\end{array}$ \\
\hline $\begin{array}{l}\text { Apoiar os demais } \\
\text { professores, analista } \\
\text { de informática e } \\
\text { bibliotecária. } \\
\text { Apoiar as ações da } \\
\text { coordenação } \\
\text { pedagógica. }\end{array}$ & $\begin{array}{l}\text { Professora } \\
\text { Orientadora de } \\
\text { Estudos }\end{array}$ & $\begin{array}{l}\text { Conhecimento: Professora experiente } \\
\text { de Pedagogia. Possui conhecimentos } \\
\text { de Informática. Assumiu as aulas de } \\
\text { Orientação de Estudo e vem } \\
\text { desenvolvendo um ótimo trabalho com } \\
\text { os alunos. } \\
\text { Habilidades: Organizar e estimular } \\
\text { situações de aprendizagem, envolver } \\
\text { os alunos no dia a dia, trabalha em } \\
\text { equipe, participa da gestão do projeto, } \\
\text { utiliza as novas tecnologias. Boa } \\
\text { comunicação. } \\
\text { Atitudes: Valorizar o trabalho dos } \\
\text { alunos, trabalhar em parceria com } \\
\text { outros profissionais, responsabilidade e } \\
\text { ética profissional. }\end{array}$ \\
\hline $\begin{array}{l}\text { Apoiar o professor de } \\
\text { Língua Portuguesa e } \\
\text { orientar os alunos }\end{array}$ & Bibliotecária & $\begin{array}{l}\text { Conhecimento: Curso de } \\
\text { Biblioteconomia, contadora de estórias }\end{array}$ \\
\hline $\begin{array}{l}\text { sobre as leituras e } \\
\text { escrita. }\end{array}$ & & $\begin{array}{l}\text { e técnicas de Origami. } \\
\text { Habilidades: Organizar, envolver os } \\
\text { alunos nas atividades da Biblioteca, } \\
\text { trabalhar em equipe. } \\
\text { Atitudes: Valorizar a aprendizagem } \\
\text { através da leitura, criatividade e } \\
\text { responsabilidade. }\end{array}$ \\
\hline
\end{tabular}




\section{O mundo do mel}

\begin{tabular}{c|l|l}
\hline $\begin{array}{c}\text { Orientar os alunos } \\
\text { nas pesquisas, na } \\
\text { digitação, na } \\
\text { formatação e na } \\
\text { elaboração do livro } \\
\text { digital. }\end{array}$ & $\begin{array}{l}\text { Conhecimento: Curso de Informática. } \\
\text { Mestrado em informática na } \\
\text { alfabetização. }\end{array}$ \\
$\begin{array}{c}\text { Informática } \\
\text { Habilidades: Organizar, envolver os em }\end{array}$ & $\begin{array}{l}\text { situações de aprendizagem através da } \\
\text { informática. }\end{array}$ \\
& $\begin{array}{l}\text { Atitudes: Valorizar a aprendizagem } \\
\text { através da informática, criatividade e } \\
\text { responsabilidade. }\end{array}$ \\
\hline
\end{tabular}

Legenda:

Processo Pedagógico

Processo Administrativo

Processo de Apoio

\section{Plano Financeiro}

Para o desenvolvimento do projeto "O Mundo do Mel" o plano financeiro encontra-se detalhado abaixo.

Investimentos (Despesas de Capital)

\begin{tabular}{|c|c|c|c|}
\hline Item & Ano1 & Anor & Anos \\
\hline Obras e infraestrutura & 0,00 & 0,00 & 0,00 \\
\hline Material permanente & $28.958,00$ & 0,00 & 0,00 \\
\hline Notebooks & $21.584,00$ & 0,00 & 0,00 \\
\hline Multifuncional & $2.796,00$ & 0,00 & 0,00 \\
\hline Projetor Multimídia & $1.599,00$ & 0,00 & 0,00 \\
\hline Tela de Projeção c/tripé & 470,00 & 0,00 & 0,00 \\
\hline Caixa Amplificada VIP 200 & $1.799,00$ & 0,00 & 0,00 \\
\hline Microfone sem Fio - Karsect & 710,00 & 0,00 & 0,00 \\
\hline Total & $28.958,00$ & 0,00 & 0,00 \\
\hline
\end{tabular}

\section{Detalhamento}

- Notebook Asus Vivobook X202e-ct266h Champanhe Intel囚 CoreTM i3 2365m 4gb, HD 500gb LED 11.6" Touch W8, valor unitário $\mathrm{R} \$ 1.349,00$.

- Multifuncional HP Officejet Pro 8600 - Eprint, Impressão, Cópia, Digitalização, Web, Fax, valor unitário R\$ 699,00 .

- Projetor Multimídia Epson Powerlite $\$ 12+$, valor unitário R $\$ 1.599,00$.

- Tela de Projeção Tripé Standar TLT S180 x 180 - 100' - Tecido vinil, valor unitário R\$ 470,00.

- Caixa Amplificada: VIP 200 Frontal Ativo 160 Watts - Leac's, valor unitário R\$1.799,00.

- Microfone sem Fio - Karsect KRU 302, valor unitário R\$710,00.

\section{Despesas correntes}




\section{Maria Cássia Sobreiro Dias Caldas}

\begin{tabular}{|c|c|c|c|}
\hline \multicolumn{4}{|l|}{ Projeção das Despesas Correntes } \\
\hline Material de Consumo & Total ANO 1 & Total ANO 2 & Total ANO 3 \\
\hline Papel Sulfite A-4 & 136,00 & 144,16 & 152,80 \\
\hline Pen Drive Sandisk Cruzer 4gb & 318,40 & 337,50 & 357,75 \\
\hline CD & 55,60 & 0,00 & 0,00 \\
\hline Cartuchos de tinta impressora & 958,40 & $1.015,90$ & $1.076,85$ \\
\hline \multirow[t]{3}{*}{ Material de desenho e pintura } & 500,00 & 530,00 & 561,80 \\
\hline & 0,00 & 0,00 & 0,00 \\
\hline & 0,00 & 0,00 & 0,00 \\
\hline Total & $1.968,40$ & $2.027,56$ & $2.149,20$ \\
\hline Passagens e Locomoção & Total ANO 1 & Total ANO 2 & Total ANO 3 \\
\hline \multirow[t]{3}{*}{ Locação de ónibus } & 405,00 & 429,30 & 455,05 \\
\hline & 0,00 & 0,00 & 0,00 \\
\hline & 0,00 & 0,00 & 0,00 \\
\hline $\begin{array}{l}\text { Total } \\
\end{array}$ & 405,00 & 429,30 & 455,05 \\
\hline Serviços de Terceiros & Total ANO 1 & Total ANO 2 & Total ANO 3 \\
\hline Buffet - Café & $4.050,00$ & 0,00 & 0,00 \\
\hline Buffet - Coquetel & $8.100,00$ & $8.586,00$ & $9.101,16$ \\
\hline Diagr. e impressão dos livros & $1.000,00$ & $1.060,00$ & $1.123,60$ \\
\hline Marcador de livro & 120,00 & 127,20 & 134,83 \\
\hline Folder - 2 dobras $21,7 \times 29,7$ & 240,00 & 254,40 & 269,66 \\
\hline Banner de lona 70 x120 & 700,00 & 0,00 & 0,00 \\
\hline Publicação de matéria no jornal & 400,00 & 212,00 & 224,72 \\
\hline \multirow[t]{3}{*}{ Convite $9 \times 15$} & 462,00 & 155,82 & 165,17 \\
\hline & 0,00 & 0,00 & 0,00 \\
\hline & 0,00 & 0,00 & 0,00 \\
\hline $\begin{array}{lcl} & \text { Total }\end{array}$ & $15.072,00$ & $10.395,42$ & $11.019,14$ \\
\hline Total das Despesas Correntes & $17.445,40$ & $12.852,28$ & $13.623,39$ \\
\hline
\end{tabular}

\section{Detalhamento}

- Resmas de Papel Sulfite A-4, valor unitário $R \$ 17,00$.

- Pen Drive Sandisk Cruzer Blade 4gb, valor unitário $R \$ 19,90$.

- Caixa de CD com 100 unidades, valor unitário $R \$ 55,60$.

- Cartuchos de tinta para impressora, valor unitário $R \$ 59,90$.

- Diversos tipos de material de desenho e pintura, valor de $R \$ 500,00$.

- Locações de ônibus para a excursão, valor unitário $R \$ 135,00$.

- Buffet para coffe break - Lançamento do projeto, valor unitário $\mathrm{R} \$ 9,00$.

- Buffet para coquetel - Lançamento do Livro (anual), valor unitário $R \$ 27,00$.

- Diagramação e impressão de livros, valor unitário $R \$ 2,50$. Impressão de marcador de livro, valor unitário $R$ \$ 0,30 . Folders - 2 dobras $21,7 \times 29,7 \mathrm{~cm}$, valor unitário $\mathrm{R} \$ 1,20$. Publicações de matéria no jornal da cidade, valor unitário $\mathrm{R} \$ 200,00$.

- Convite $9 \times 15 \mathrm{~cm}$ para lançamento do projeto e do livro, valor unitário $R \$ 0,70$. 
Despesas Administrativas e de Pessoal

*Valor utilizado como contrapartida

\begin{tabular}{|c|c|c|c|}
\hline \multicolumn{4}{|c|}{ Projeção das Despesas Administrativas e de Pessoal } \\
\hline Administrativas & Total ANO 1 & Total ANO 2 & Total ANO 3 \\
\hline Energia Elétrica & $3.540,00$ & $3.752,40$ & $3.977,54$ \\
\hline Água & $3.900,00$ & $4.134,00$ & $4.382,04$ \\
\hline Total & $7.440,00$ & $7.886,40$ & $8.359,58$ \\
\hline Pessoal & Total ANO 1 & Total ANO 2 & Total ANO 3 \\
\hline Administrador de U. Escolar & $1.435,80$ & $1.521,95$ & $1.613,26$ \\
\hline Coordenador Pedagógico & $2.343,60$ & $2.484,22$ & $2.633,27$ \\
\hline Professor de Língua Portuguesa & $3.440,88$ & $3.647,33$ & $3.866,17$ \\
\hline Professor de Arte & $2.293,92$ & $2.431,56$ & $2.577,45$ \\
\hline Prof. Orientador de Estudo & $2.293,92$ & $2.431,56$ & $2.577,45$ \\
\hline Analista de Informática & $1.489,32$ & $1.578,67$ & $1.673,41$ \\
\hline Bibliotecária & $1.769,04$ & $1.875,18$ & $1.987,69$ \\
\hline $\begin{array}{l}\text { Total } \\
\text { Th }\end{array}$ & $15.066,48$ & $15.970,47$ & $16.928,70$ \\
\hline \begin{tabular}{|c|} 
Total das Despesas \\
Administrativas e de Pessoal
\end{tabular} & $22.506,48$ & $23.856,87$ & $25.288,28$ \\
\hline
\end{tabular}

Necessidade de Recursos

\begin{tabular}{|l|c|c|c|c|}
\hline \multicolumn{4}{|c|}{ Cálculo da Necessidade de Recursos } \\
\hline \multicolumn{1}{|c|}{ Item } & ANO 1 & ANO 2 & ANO 3 & TOTAL \\
\hline I. Total das Despesas Correntes & $\mathbf{1 7 . 4 4 5 , 4 0}$ & $\mathbf{1 2 . 8 5 2 , 2 8}$ & $\mathbf{1 3 . 6 2 3 , 3 9}$ & $\mathbf{4 3 . 9 2 1 , 0 7}$ \\
\hline Material de Consumo & $1.968,40$ & $2.027,56$ & $2.149,20$ & $6.145,16$ \\
\hline Passagens e Despesas com Locomoção & 405,00 & 429,30 & 455,05 & $1.289,35$ \\
\hline Serviços de Terceiros & $15.072,00$ & $10.395,42$ & $11.019,14$ & $36.486,56$ \\
\hline II. Total de Despesas Administrativas & $\mathbf{7 . 4 4 0 , 0 0}$ & $\mathbf{7 . 8 8 6 , 4 0}$ & $\mathbf{8 . 3 5 9 , 5 8}$ & $\mathbf{2 3 . 6 8 5 , 9 8}$ \\
\hline III. Total de Despesas com Pessoal & $\mathbf{1 5 . 0 6 6 , 4 8}$ & $\mathbf{1 5 . 9 7 0 , 4 7}$ & $\mathbf{1 6 . 9 2 8 , 7 0}$ & $\mathbf{4 7 . 9 6 5 , 6 5}$ \\
\hline $\begin{array}{l}\text { IV. Total de Despesas de Capital } \\
\text { (investimentos) }\end{array}$ & $\mathbf{2 8 . 9 5 8 , 0 0}$ & $\mathbf{0 , 0 0}$ & $\mathbf{0 , 0 0}$ & $\mathbf{2 8 . 9 5 8 , 0 0}$ \\
\hline Necessidade de Recursos (I+II+III+IV) & $\mathbf{6 8 . 9 0 9 , 8 8}$ & $\mathbf{3 6 . 7 0 9 , 1 5}$ & $\mathbf{3 8 . 9 1 1 , 6 7}$ & $\mathbf{1 4 4 . 5 3 0 , 7 0}$ \\
\hline Recursos Edital & $46.403,40$ & $12.852,28$ & $13.623,39$ & $\mathbf{7 2 . 8 7 9 , 0 7}$ \\
\hline Recursos da Organização (contrapartida) & $22.506,48$ & $23.856,87$ & $\mathbf{2 5 . 2 8 8 , 2 8}$ & $\mathbf{7 1 . 6 5 1 , 6 3}$ \\
\hline
\end{tabular}


Validações

\begin{tabular}{|c|c|c|c|}
\hline Itens Financiáveis & $\begin{array}{c}\text { Valores } \\
\text { Consolidados }\end{array}$ & $\%$ & Validação \\
\hline Despesas Correntes & $43.921,07$ & $60,27 \%$ & - \\
\hline Despesas de Capital & $28.958,00$ & $39,73 \%$ & Ok: $<50 \%$ \\
\hline $\begin{array}{c}\text { Total de Recursos } \\
\text { Solicitados }\end{array}$ & $72.879,07$ & $100 \%$ & $\begin{array}{c}\text { Ok: }< \\
100.000,00\end{array}$ \\
\hline
\end{tabular}

\section{Contrapartida}

\begin{tabular}{|c|c|}
\hline \multicolumn{2}{|c|}{ Contrapartida } \\
\hline Valor total da contrapartida & $\mathbf{R} \$ \mathbf{7 1 . 6 5 1 , 6 3}$ \\
\hline Valor solicitado ao edital pelo projeto & $\mathbf{R} \$ \mathbf{7 2 . 8 7 9 , 0 7}$ \\
\hline Percentual contrapartida / recursos solicitados & $\mathbf{9 8 , 3 1 \%}$ \\
& Ok: $>10 \%$ \\
\hline
\end{tabular}

O projeto em questão estima a utilização de recursos próprios no valor de $\mathrm{R} \$ 71.651,63$ (setenta e um mil, seiscentos e cinqüenta e um reais e sessenta e três centavos) e necessita de $R \$ 72.879,07$ (setenta e dois mil, oitocentos e setenta e nove reis e sete centavos) oriundos dos recursos do Edital para a execução do mesmo. O percentual da contrapartida oferecido é de $98,31 \%$ dos recursos solicitados, atendendo plenamente aos pré-requisitos do Edital publicado da Fundação Novo Brasil. 